\title{
125 セミドライ加エで環境、省エネへの取り組み
}

Environmental improvement and energy saving with MQL machining method

成澤 保広 0 藤原 吏志 (エヌティーッール株式会社).

Yasuhiro NARUSAWA Satoshi FUJIWARA, NT TOOL CORPORATION

1-7·10, Yoshikawa·cho, Takahama-city, Aichi

\begin{abstract}
MQL (Minimum Quantity Lubrication) machining method attracts more and more attentions in production facilities for energy conservation and environmental protection. This innovative way of machining utilizes small amount of lubrication oil and compressed air instead of much water soluble coolant.

Our "MQL Collet System" is most suitable for MQL machining method. Collet has 6 oil-jet splay nozzles in internal diameter for securing sufficient amount of lubrication oil in use of a small diameter tools and high precision aluminum machining.

We introduce MQL collet system based on semi-dry actual cutting examples.
\end{abstract}

\section{1.はじめに}

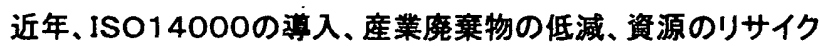
ル化と生産工場における瀷境対策の改善は確実に歩み始めて いる。切削加工分野においては、完全に切削油を使用しないドラ イ加工、加工点に最小限のミスト状切削油をエアとともに供給す るMQL(Minimum Quantity Lubrication) 加工法が注目されている。 一部の大手企業ではすでにMQL加工法による製造ライン゙が実 用化され、翼境改善や省エネルギ一効果を出しており 今後さら に展開されると思われる。

ここでは、実際の加工事例を基にMQL加エに最適なッーリン グシステムを紹介する。

\section{2.オイルミスト発生装置とその原理}

ミスト発生装置はいくつかのメーカーより発売され、多岐の選 択肢があるが、ここでは外部ミキシング型と呼ばれる工作機械の 外部でオイルミストを生成する方法について原理に触れる。
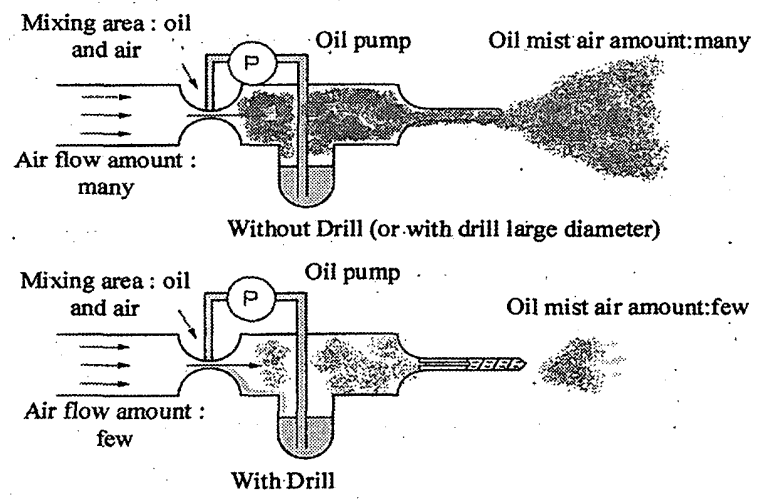

Fig 1 : Principle of oil-air mixing

Fig 1 にオイルミスト発生原理を示す。ミスト発生装置の原理は 雾吹きの原理と同しといえる。雾化部(Mixing area)を通過する、 エア量が大きい埸合は吐出するオイルミストが多く、エア胃が少 ない場合、吐出されるオイルミストは少なくなる。
特に小径のドリル加エの場合オイルホール断面皘が極めて小さ く、エア流量不足による刃先への油剂供給量不足が墨念される。

\section{MQL加エ用 コレットシステム}
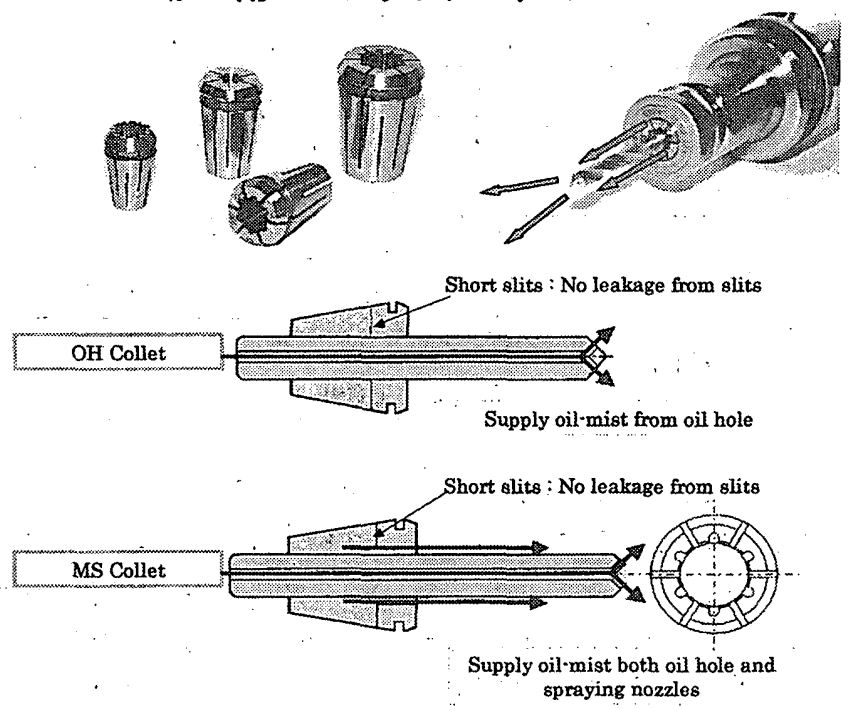

Fig 2 : Structure of MQL collet system

Fig 2 にMQL加エ用コレットを示す。このシステムは当社独特の システムであり、エ具のオイルホールより油剤供給するOHコレッ トと、エ具のオイルホールに加えエ具外周からも油剤を供給する MSコレットがある。

MSコレットはOHコレットの内径部に噴射ノスルを設けた構造 になっている。このノズは、先に述べたようにオイルホール径 の小さいエ具を使用する埸合に起こる、エア流貫不足によって加 エに必要な油剤量が確保できないケースにおいてノスルからの エア噴出でエア流量を確保し、必要十分な油剤を加エ点に供給 する役目をする。

また、工具外周からの油剂供給は、クランクシャフト油穴のよう な深穴加エや、切りくずが溶着しやすいアルミニウム加エによう に油剂を多く必要とする加工で効果を上げることができる。

日本機械学会 [No.04-3］第 5 回生産加工・工作機械部門講演会講演論文集 ['04-11-20,21,吹田] 


\section{4. 加工事例}

SCM415合金鋼に穴径 $\phi 4 \mathrm{~mm}$ 、深さ77 mmの深穴加工事 例を示す。(Fig3) こうしたし/D $=20$ 程度の深穴加エでのセミド ライ加エでは、エ具オイルホールからの油郕供給だけでなくエ具 外周からも油用を供給するFDCーMSコレットが効果的である。

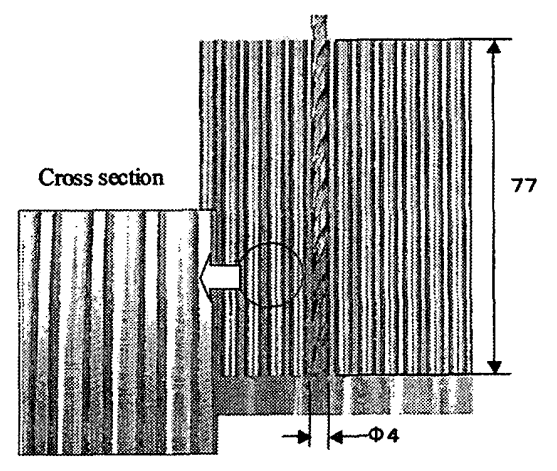

Fig 3: MQL cutting example $\phi 4$ Long drill with oil hole

\begin{tabular}{l|l}
\multicolumn{1}{c}{ 加工条件 (Cutting conditions) } \\
\hline Workpiece & SCM415 (Alloy steel) \\
\hline Cutting tool & $\begin{array}{l}\text { MITSUBISHI MATERIAL } \\
\text { Carbide drill with oil hole } \phi 4 \times 100\end{array}$ \\
\hline Cutting speed & V=80m/min (6366/min) \\
\hline Feed & $\mathrm{f}=0.15 \mathrm{~mm} / \mathrm{rev}$ (955mm/min) \\
\hline Cutting depth & $\mathbf{7 7 m m ~ ( N o n ~ s t e p ~ f e e d ) ~}$ \\
\hline MQL device & $\begin{array}{l}\text { EBARA Ecomist MBM02 } \\
\text { Vegetable oil Air Pressure 0.5MPa }\end{array}$ \\
\hline Tool holder & $\begin{array}{l}\text { BT50-HDC07-90 (Collet Holder) } \\
\text { Collet :FDC-04007-MSAA }\end{array}$ \\
\hline
\end{tabular}

この加工例では、OHコレットとMSコレットを用いて加エをした が、Hコレットでは1回目は402穴でドリルが折損、2回目は54 8穴でドリルが折損する結果となった。これと比較しエ異オイルホ 一ルとエ具外周から油昘を供給するMSコレットを用いた加エで は、2回の加エいずれも1200穴を加エしても工具欠提なく加エ 維繶可能な状態であった。工具寿命は2倍以上向上していること が確認できる。

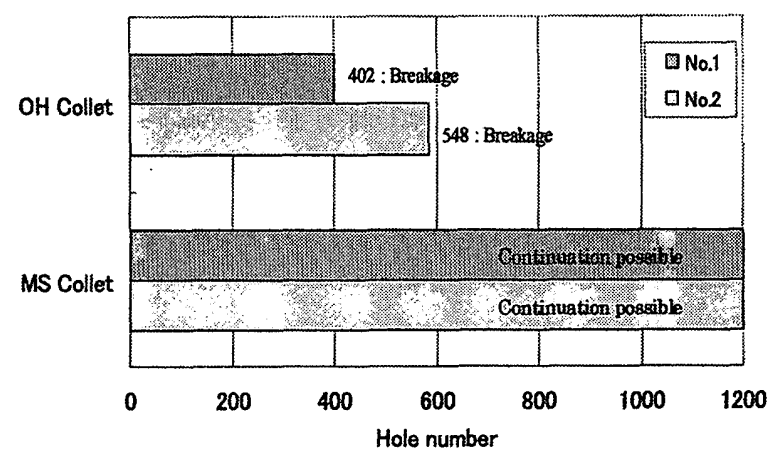

Fig 4: The result of MQL deep hole drilling
Fig 5 にコレットの螘い(OH, MS)による加エした穴の加工面比 較を示す。

これらから分かるようにMSコレットを用いた加エでは加エ穴側 面に大きなキズはみられず潤滑の効果が確認できた。 ○Hコレットを用いた加エでは、切りくずがドリルに巻きついてでき たと思われる円周方向のキズが、穴底付近に多く見られた。

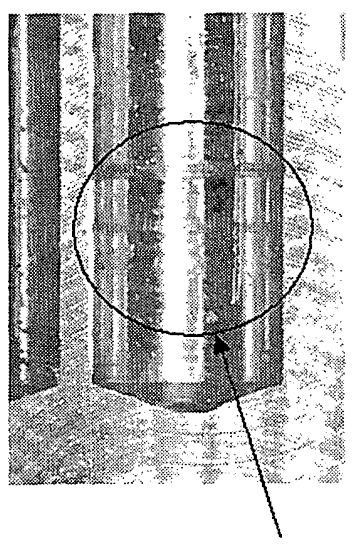

OH Collet

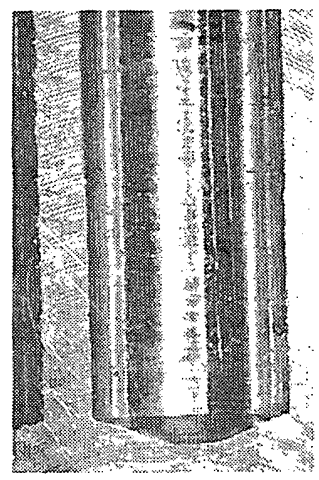

MS Collet
Fig 5: Picture for deep hole cross section

さらに、潤滑効果の裹付けを確認するため、OHコレットとMSコ レットを用いたときの油剂供給量を比較した。

刃先に供給される全油剤皇については、MSコレットを用いた場 合、吐出開放断面䅪がオイルホールに比べ極めて大きく、油剂 供給盢が20倍以上多い結果となった。

また、MSコレットを用いた時のエ具外周からの供給油剤を除 去しオイルホールのみから供給される油年を計測したところ、OH コレットを用いた塌合の3倍以上の油置が確認された。

MSコレットを使用した堨合、工具外周部へ油剤が逃げてしまい 肝心のオイルホールからの油剤供給が減少するといったイメージ を持たれることが多いが、工具把握部分まで適切なエア流量を確 保し、オイルミストをロスなく多く搬送できるMQLコレットシステム により、結果的にオイルホールからの油戍供給異が増加したもの と思われる。

\section{5.まとめ}

MQL加エに最適な、コレットシステムFDCーMS型を使用する ことにより以下の効果を確認できた。

(1):工具表命の向上

(2):加工面状態が良い

(3): 小径オイルホール付きドリル使用時の油剤供給量 の増大

また、MQLコレットシステムを使用してアルミニウム部品加エを 行っているユーザーからは、溶着による加工不具合が解消され たとの報告もある。

セミドライ加エ技術はまだ多くの課題を残しているが、当社製品 が今後のセミドライ展開の一助となれば幸いである。 